\title{
The Heterogeneous Effects of COVID-19 Outbreak on Stock Market Returns and Volatility: Evidence from Panel Quantile Regression Model
}

\author{
Noreen Khalid ${ }^{1 *}$, Raja Fawad Zafar'2, Qasim Raza Syed ${ }^{3}$, \\ Roni Bhowmik', Muhammad Jamil ${ }^{5}$ \\ 'Quad-i-azam University, Islamabad, Pakistan \\ ${ }^{2}$ Sukkur IBA University, Pakistan \\ ${ }^{3}$ National Tariff Commission, Ministry of Commerce, Pakistan \\ ${ }^{4}$ Guangdong University of Foreign Studies, China \\ ${ }^{5}$ University of Azad Jammu and Kashmir, Pakistan \\ E-mail: 'noreen123qau@gmail.com, 2fzraja@yahoo.com, 33qasimrazasyed.economics@gmail.com, \\ ${ }^{4}$ roni@amss.ac.cn, ${ }^{5}$ mjamil@qau.edu.pk
}

${ }^{*}$ Corresponding Author

\section{JEL Classification:}

G24

G30

$\mathrm{O} 16$

Received: 04 May 2021

Revised: 23 August 2021

Accepted: 30 August 2021

\begin{abstract}
The purpose of this study is to probe the impact of the novel coronavirus (COVID-19) outbreak on stock market returns and volatility in developed markets. We employ a panel quantile regression model to capture unobserved individual heterogeneity and distributional heterogeneity. The study's findings reveal that there is a heterogeneous impact of COVID-19 on stock market returns and volatility. More specifically, there is a negative impact of COVID-19 on stock returns in the bearish stock market; however, there is an insignificant impact of COVID-19 on stock returns in the bullish stock market. Furthermore, COVID-19 has a positive impact on stock market volatility across all quantiles.

Keywords:

Coronavirus, covid-19, stock market returns, volatility, panel quantile regression model
\end{abstract}

How to Cite:

Khalid, N., Zafar, R. F., Syed, Q. R., Bhowmik, R., \& Jamil, M. (2021). The Heterogeneous Effects of COVID-19 Outbreak on Stock Market Returns and Volatility: Evidence from Panel Quantile Regression Model. Etikonomi, 20(2), 225 - 238. https://doi.org/10.15408/etk.v20i2.20587. 


\section{Introduction}

There are a plethora of studies that investigate the factors that affect stock market returns and volatility. However, one strand of literature probes the impact of events on stock market returns and volatility. These events include; sports (Buhagiar et al., 2018), news (Li, 2018), environmental (Alsaifi et al., 2020; Guo et al., 2020), disasters (Kowalewski \& Śpiewanowski, 2020), and political events (Bash \& Alsaifi, 2019; Shanaev and Ghimire, 2019). Thus far, there is limited literature that examines the effect of pandemic diseases (e.g., SARS and EVD outbreak) on stock markets (Chen et al., 2007, 2009; Ichev \& Marinč, 2018). Therefore, it is essential to scrutinize the impact of pandemic diseases on stock market returns and volatility.

Parallel to this, on December 31, 2019, WHO (world health organization) reported the first case of novel coronavirus (COVID-19) in China. This virus has spread to almost every country of the world. As of May 5, 2020, there were 4014436 confirmed cases of coronavirus around the globe. Countries worldwide follow protective measures to mitigate the spread of this outbreak, such as the social distancing and lockdown policy. Therefore, this outbreak has enormous economic impacts. The global GDP growth rate has plunged due to the coronavirus outbreak. Energy markets are also affected by this outbreak. On March 23th, 2020, Brent oil prices plunged about 24\%. Next, the manufacturing industry has been affected by the coronavirus outbreak. $98 \%$ of respondents of a survey conducted by the British Plastics Federation speculate that the coronavirus outbreak has harmed the manufacturing industry in the next few quarters.

Moreover, there is also a surge in the unemployment rate due to this outbreak. Thirty million people have become unemployed in the US within few months due to this coronavirus outbreak. Furthermore, it is well known that investment and doing business positively impacted economic development (Činčalová et al., 2021). However, the COVID-19 pandemic adversely impacts investment and doing business (Donthu \& Gustafsson, 2020). Moreover, the COVID-19 pandemic also hits the creative industry (Bhowmik et al., 2021). Next, Baker et al. (2020a) note that coronavirus outbreak generates economic policy uncertainty. Next, Baker et al. (2020b) conclude that the coronavirus pandemic decreases household spending. Sharif et al. (2020) find that the COVID-19 outbreak affects economic policy uncertainty, geopolitical risk, oil prices, and stock markets. Thus, the novel coronavirus (COVID-19) outbreak affects each sector of an economy.

Coronavirus outbreak has profound impacts on stock markets. Researchers have been examining the relationship between the stock market and COVID-19 since the pioneer study of Goodell (2020). Yarovaya et al. (2020) propose a conceptual framework that could be used to investigate the relationship between pandemics (e.g., COVID-19) and the Stock market. In this background, Ashraf (2020) examines the effect of COVID-19 on stock markets using pooled OLS, fixed effect, and random effect models. The author reports that COVID-19 harms stock market returns. Baker et al. (2020c) investigate the impact of coronavirus on the stock market through newspaper articles. The findings of the study conclude that stock market returns decrease due to coronavirus. However, coronavirus increases the volatility in the stock market. 
Similarly, Liu et al. (2020) probe the effect of coronavirus outbreaks on stock markets of developed countries using event study analysis. The findings from the study show that the coronavirus outbreak affects the stock market returns and volatility. Moreover, Zhang et al. (2020) employ a minimum spanning tree approach and conclude that coronavirus outbreak surges the stock market volatility. Al-Awadhi et al. (2020) employ a panel fixed effect model and note that the coronavirus outbreak negatively impacts stock market returns in China. Further, the study also concludes that coronavirus outbreaks positively impact a few sectors (e.g., medical, information technology, and medical). The studies above on the relationship between COVID-19 and stock markets mainly employed panel data regression models (e.g., fixed effect model). There is a limitation of these studies above, such as they ignore the unobserved individual heterogeneity and distributional heterogeneity. If we overlook these heterogeneities above, then we may get misleading results.

There is a limited amount of literature that explores the impact of outbreaks on stock markets. This section, therefore, reviews some studies that investigate the effects of outbreaks on stock markets. Delisle (2003) investigates the cost of the SARS outbreak and finds that the SARS outbreak has a significant impact on the financial market. Further, the author reports that the economic cost of the SARS outbreak is almost equal to the cost of the global financial crisis. Similarly, Nippani \& Washer (2004) examine the effect of the SARS outbreak on stock markets and note that the SARS outbreak harms the stock markets of China and Vietnam. Next, Del Giudice \& Paltrinier (2017) probe the impact of Arab Spring and the Ebola outbreak on equity markets. The findings reveal that their equity markets are affected by these outbreaks above.

Moreover, Macciocchi et al. (2016) scrutinize the effect of the Zika virus outbreak on stock markets and report that there is a negative relationship between the Zika virus outbreak and the stock market in the case of Brazil. Chen et al. (2007) note that the SARS outbreak negatively affects the hotel stocks. Wang et al. (2013) conclude that outbreaks caused by any infectious disease affect biotechnology stock. Moreover, Conlon \& McGee (2020) conclude that bitcoin does not behave like a safe haven during the COVID-19 pandemic. Next, Goodell \& Goutte (2020) also find that COVID-19 escalates the prices of bitcoin.

Recently, Bouri et al. (2021a) used DECO-GARCH models on selected industries of the New Zealand stock market to explore the effect of three policies, namely, the lockdown, the stimulus package, and the travel ban. The study's findings conclude that there is a heterogeneous impact of these policies on selected stock indices. Moreover, healthcare, technology, and real estate stock indices are found immune to these policies. Next, Abuzayed et al. (2021) examine the systematic risk spillovers between global and selected countries' stock markets using DCC-GARCH models during the COVID-19 period. The findings reveal that the spillovers are profound during the COVID-19 pandemic.

Moreover, Bouri et al. (2021b) employ the TVP-VAR connectedness approach to investigate the connectedness among selected financial assets during the COVID-19 
pandemic. The results show that the Bond and USD indices are the net transmitter, while the equity indices are the net receiver. Furthermore, a few research outlets examine the safe haven properties between gold and Asian stock markets during the COVID-19 outbreak (Yousaf et al., 2021). Parallel to this, a line of research explores the asymmetric volatility spillover between stock markets during the COVID-19 pandemic (see, e.g., Shahzad et al., 2021).

Similarly, using two-step GARCH models, Hoang \& Syed (2021) probe whether VIX and CSFB predict the volatility of currencies and commodities in the pre-and postCOVID-19 period. The results note that both VIX and CSFB do not explain the volatility of currencies and commodities during COVID-19. Likewise, Hashmi et al. (2021) explore the asymmetric impact of the COVID-19 outbreak on stock prices of the E7 economies. The findings from quantile-on-quantile regression reveal the asymmetric impact of the COVID-19 pandemic on selected stock indices. Yousfi et al. (2021) compare the correlation between US and China stock markets for the first and second waves of the COVID-19 outbreak. The findings reveal that correlation between the considered stock markets is relatively profound during the COVID-19 period. One strand of the COVID-19 \& stock market literature uses event study analysis. For instance, Sun et al. (2021) noted that the COVID-19 had a detrimental impact on the Chinese stock market during the pandemic. Recently, Gao et al. (2021) used a wavelet-based QQ regression approach to examine the effect of the volatility of the COVID-19 outbreak on the volatility of the US and Chinese stock market. The study finds that the COVID-19 pandemic positively impacts US stock market volatility, and that effect is relatively significant compared to the effect on the Chinese stock market. Likewise, Rahman et al. (2021) also reported that the COVID-19 outbreak harms the stock market in the case of Australia.

In this background, the present study scrutinizes the impact of coronavirus outbreaks on stock market returns and volatility in developed markets. This study contributes to the literature in three ways. First, as there are limited studies that probe the impact of outbreaks on stock markets, the present study fills this gap. Second, the present study employs a panel quantile regression model that captures the unobserved individual and distributional heterogeneity. Besides, this model also minimizes the problems of heteroscedasticity, multicollinearity, and estimation bias (Baltagi, 2008; Woolridge, 2010). Next, to the best of our knowledge, no study investigates the impact of coronavirus outbreaks on stock markets during different trends (e.g., bearish, normal, and bullish). Therefore, this study fills this gap by scrutinizing the impact of covid-19 on bearish, normal, and bullish stock markets. Furthermore, this study provides empirical evidence on whether COVID-19 affects stock returns and volatility in developed stock markets to help investors and policymakers in portfolio diversification and policy implications.

\section{Methods}

The purpose of this study is to investigate the impact of novel coronavirus outbreaks on stock market returns and volatility using a panel quantile regression model. The study uses daily data ranging from December 30, 2019, to March 24, 2020. Further, 
we use seventeen developed stock markets, including Austria, Australia, Canada, Finland, France, Germany, Ireland, Japan, Netherlands, New Zealand, Norway, Spain, Singapore, Sweden, Switzerland, US, and the UK. Further, we choose countries and periods based on data availability.

Further, we also take log differences of stock prices data in order to calculate stock returns. Moreover, to calculate volatility, we employ the GARCH $(1,1)$ model on stock prices. The key independent variable of the present study is the number of daily deaths from coronavirus pandemics. The data on deaths from coronavirus are taken from World Health Organization (WHO) database. The study also includes daily oil prices as a control variable to eradicate omitted variable bias. Furthermore, we convert all independent variables into log difference series.

Table 1. Summary of Descriptive Statistics

\begin{tabular}{cccc}
\hline & COVID & Oil & Stock \\
\hline Mean & 0.377443 & -0.001481 & -0.198646 \\
Std. Dev. & 1.052633 & 0.032201 & 1.288404 \\
Skewness & 3.319868 & -0.589610 & -0.659903 \\
Kurtosis & 14.28354 & 10.16411 & 8.628119 \\
Jarque-Bera & $(0.000000)^{* * *}$ & $(0.000000)^{* * *}$ & $(0.000000)^{* * *}$ \\
\hline
\end{tabular}

Note: "COVID" shows deaths from coronavirus. "oil" shows log difference of oil prices, and "stock" represents stock returns. (.) is the p-value. Also, ${ }^{*}, * * * * *$ represents level of significance at $10 \%, 5 \%$, and $1 \%$.

Table 1 reports descriptive statistics of all data series. As can be seen, on average, stock market returns and oil returns are negative. Moreover, stock market returns are highly volatile as the standard deviation value is highest for stock market returns. Next, all data series are skewed. Further, kurtosis illustrates that the tails of all variables are thick. At last, the Jarque-Bera test concludes that all variables are not normally distributed. As the data are not normally distributed, employing OLS (ordinary least square) may give misleading results (Binder \& Coad, 2011). Thus, it is appropriate to employ quantile regression methodology.

Table 2. Summary of Unit Root Tests

\begin{tabular}{ccccccc}
\hline Unit root test & $\begin{array}{c}\text { COVID } \\
\text { I (0) }\end{array}$ & $\begin{array}{c}\text { Oil } \\
\mathbf{I}(\mathbf{0})\end{array}$ & $\begin{array}{c}\text { Stock } \\
\mathbf{I}(\mathbf{0})\end{array}$ & $\begin{array}{c}\text { COVID } \\
\mathbf{I}(\mathbf{1})\end{array}$ & $\begin{array}{c}\text { Oil } \\
\mathbf{I}(\mathbf{1})\end{array}$ & $\begin{array}{c}\text { Stock } \\
\mathbf{I}(\mathbf{1})\end{array}$ \\
\hline LLC- test & $(0.42)$ & $(0.23)$ & $(0.14)$ & $(0.00)^{* *}$ & $(0.00)^{* *}$ & $(0.02)^{* *}$ \\
ADF - Fisher & $(0.21)$ & $(0.11)$ & $(0.27)$ & $(0.00)^{* *}$ & $(0.01)^{* *}$ & $(0.00)^{* *}$ \\
PP - Fisher test & $(0.13)$ & $(0.24)$ & $(0.10)$ & $(0.00)^{* *}$ & $(0.00)^{* *}$ & $(0.00)^{* *}$ \\
\hline
\end{tabular}

Note: (.) is p-value. ${ }^{* *}$ shows level of significance at $5 \%$.

Table 2 demonstrates the results from unit root tests. We apply three different unit root tests to discern the order of integration of data. The results from these tests 
reveal that all variables have the problem of unit root at the level. Further, all variables are stationary at the first difference at a 5\% level of significance.

We employ a panel quantile regression model to probe the impact of novel coronavirus outbreaks on stock market returns in developed economies. This model describes the impact of coronavirus outbreak on all selected quantiles of stock market returns and volatility. Most of the time, studies employ traditional OLS methodology, leading to misleading results due to the non-normal distribution of data. On the contrary, quantile regression gives unbiased \& efficient results even in the case of non-normal distribution. Moreover, this methodology is not outlier sensitive, which is another advantage of this methodology. These properties above quantile regression prompt many researchers to employ this methodology.

$$
Q_{y i}\left(\varnothing \mid x_{i}\right)=x_{i}^{\prime} \alpha_{\varnothing}
$$

Equation (1) demonstrates the conditional quantile $\mathrm{Yi}$ in a given xi. However, $\varnothing$ it denotes the quantile. While using quantile regression methodology in panel data, unobserved heterogeneity is taken into account, which prompts a panel quantile regression model with a fixed effect. This model enables us to control unobserved individual heterogeneity. The panel quantile regression model with fixed effect is mentioned as follows.

$$
Q_{y i t}\left(\varnothing_{k} \mid \varphi_{i}, x_{i t}\right)=\varphi_{i}+x_{i t}^{\prime} \alpha\left(\varnothing_{k}\right)
$$

In equation (2), $\varphi$ i captures the fixed effect that brings the incidental parameter problem (Lancaster, 2000). With fixed time-series observations for each cross-sectional unit, the estimator becomes inconsistent when the cross-sectional unit approaches infinity (Kato \& Galvao, 2010). Thus, we cannot use conventional linear approaches in the panel quantile regression model. Koenker (2004) develops an approach known as the shrinkage method to solve the problem mentioned above of panel quantile regression. This method introduces a penalty term to eliminate the unobserved fixed effects. The parameters of the model are estimated as follows.

$$
\begin{aligned}
& \left(\hat{\alpha}\left(\emptyset_{k}, \eta\right),\left\{\varphi_{i}(\eta)\right\}^{\mathrm{N}}{ }_{\mathrm{i}=1}\right)=\arg \min \sum_{k}^{K} \sum_{t}^{T} \sum_{i}^{N} \Omega_{k} \rho_{\emptyset k}\left(y_{i t}-\varphi_{i}-x_{i t}^{-} \alpha\left(\emptyset_{k}\right)\right)+ \\
& \eta \sum_{i}^{N}\left|\varphi_{i}\right|
\end{aligned}
$$

In equation (3), "i" and " $\mathrm{t}$ " represent country and year, respectively. Further, "k" represents the quantile; however, $\rho \emptyset \mathrm{k}$ shows the quantile loss functions. Moreover, $\Omega \mathrm{k}$ shows the given weight that is assigned to $\mathrm{k}$-th quantile. $\Omega \mathrm{k}$ Captures the contribution of different quantiles. Similar to Lamarche (2011), we also set $\Omega \mathrm{k}=1 / \mathrm{k}$. $\eta$ is tunning term/parameter used to plunge the individual effect to zero for better estimation of slope coefficients in the model. We also set the value of $\eta=1$ as many studies, for instance, Zhu et al. (2018), set the value of $\eta=1$.

As this study scrutinizes the impact of coronavirus outbreak on stock market returns and volatility, we develop the panel quantile model mentioned as follows.

$$
Q_{Y i t}\left(\emptyset_{k} \mid \varphi_{i}, x_{i t}\right)=\varphi_{i}+\alpha_{1 \varnothing} \operatorname{COVID}_{i t}+\alpha_{1 \varnothing} O I L_{i t}
$$


In equation (4), we denote country and time with indices " $i$ " and " $\mathrm{t}$ " respectively. $\varphi \mathrm{i}$ shows unobserved heterogeneous effects across countries. Moreover, yit represents the stock market returns (volatility). Next, COVIDit demonstrates the number of deaths from coronavirus. To eliminate omitted-variable bias, we include an additional variable such as daily oil prices $\left(O I L_{i t}\right)$.

\section{Results and Discussion:}

We also employ pooled OLS and fixed effect models to compare these models' results with the panel quantile regression model. From panel quantile regression, we report results of 25 th percentile (bearish market), 50th percentile (normal), and 75 th percentile (bullish market) of conditional stock market returns (volatility). Table 3 reports the results from pooled, fixed effects, and panel quantile regression.

Table 3. Summary of Results for Stock Market Returns

\begin{tabular}{cccccc}
\hline \multirow{2}{*}{ Variable } & \multicolumn{2}{c}{ OLS Regression } & \multicolumn{3}{c}{ Quantile Regression } \\
\cline { 2 - 6 } & Pooled & Fixed Effects & $\mathbf{2 5}^{\text {th }}$ & $\mathbf{5 0}^{\text {th }}$ & $\mathbf{7 5}^{\text {th }}$ \\
\hline \multirow{2}{*}{ Constant } & $-0.17^{* * *}$ & $-0.17^{* * *}$ & $-0.44^{* * *}$ & -0.04 & $0.27^{* * *}$ \\
& $(0.00)$ & $(0.00)$ & $(0.00)$ & $(0.20)$ & $(0.00)$ \\
COVID & $-0.07^{* *}$ & $-0.10^{* *}$ & $-0.57^{* * *}$ & $-0.17^{* *}$ & $0.12^{*}$ \\
& $(0.04)$ & $(0.01)$ & $(0.00)$ & $(0.02)$ & $(0.05)$ \\
Oil & $-7.52^{* * *}$ & $-7.57^{* *}$ & $-8.63^{* * *}$ & $-6.60^{* * *}$ & $-3.7^{*}$ \\
& $(0.00)$ & $(0.01)$ & $(0.00)$ & $(0.00)$ & $(0.07)$ \\
\hline
\end{tabular}

Note: (.) represents the $\mathrm{p}$-value.

Also, ${ }^{*},{ }^{* *},{ }^{* * *}$ represents level of significance at $10 \%, 5 \%$, and $1 \%$.

As can be seen in Table 3, the results are heterogeneous. Pooled OLS concludes that a $1 \%$ rise in deaths from coronavirus is responsible for a $0.07 \%$ plunge in stock market returns in developed markets. Further, the slope coefficient of COVID from the fixed effects model finds that a $0.10 \%$ decline in stock returns is fostered by a $1 \%$ increase in deaths from coronavirus.

Findings from the panel quantile regression model reveal that coronavirus outbreak has a negative and statistically significant impact on stock market returns. Our findings are in line with the findings of Al-Awadhi et al. (2020), Baker et al. (2020c), and Liu et al. (2020). It is worth reporting that our results are contrary to the findings of Liu et al. (2020), who argued that the COVID-19 pandemic escalates the stock returns. Furthermore, results from panel quantile regression are also heterogeneous across the distribution. At the 25 th quantile, the coefficient of COVID is -0.57 , which means that a $1 \%$ increase in deaths reduces the stock returns by $0.57 \%$ in the bearish market.

This outcome is also backed by the findings from the study of $\mathrm{He}$ et al. (2020). Also, Apergis \& Apergis (2020) noted that the COVID-19 pandemic plunges the stock 
returns in the Chinese stock market. Meanwhile, at the 50th quantile, the coefficient of COVID describes that a $1 \%$ increase in deaths from coronavirus outbreaks will cause a $0.17 \%$ decline in stock returns. This conclusion is similar to the results of Anh \& Gan (2020), who report that the COVID-19 outbreak has a detrimental impact on the Vietnam stock market. Next, at the 75th quantile, the coefficient of COVID is statistically insignificant. It implies that the coronavirus outbreak does not affect the stock returns in the bullish market. This finding is somehow in line with Cepoi's (2020) conclusions, noting that panic due to the COVID-19 outbreak does not affect the bullish stock market.

The effect of oil prices on stock returns is also heterogeneous. At lower quantile, the effect of oil prices on stock returns is profound; however, the effect is meager and statistically insignificant at upper quantile. The results are also backed by the conclusion of Lee \& Zeng (2011), who report that oil prices plunge the stock prices at different quantiles. Moreover, Kilian \& Park (2009), and Kang et al. (2015) conclude the same findings that oil prices negatively impact stock returns. It is worth reporting that our findings are somehow backed by the conclusion from the study of Bouri (2015) and Bouri et al. (2017) that expound the impact of oil prices on the stock market. Thus, findings show a profound impact of coronavirus outbreak on stock returns at lower quantile compared to upper quantile. The findings postulate that stock returns of bearish stock markets are more vulnerable to coronavirus outbreaks than bullish markets.

Next, Table 4 reports the impact of coronavirus outbreak on stock market volatility from pooled OLS, fixed effects, and panel quantile regression model. The impact of coronavirus outbreak on stock market volatility varies from one methodology to another. In table 4, pooled regression model reveals that a $1 \%$ increase in deaths from coronavirus generates $1.43 \%$ volatility in developed stock markets. Next, the fixed effects model concludes that volatility increases by $1.55 \%$ due to a $1 \%$ increase in deaths from coronavirus outbreaks.

Table 4. Summary of Results for Stock Market Volatility

\begin{tabular}{cccccc}
\hline \multirow{2}{*}{ Variable } & \multicolumn{2}{c}{ OLS Regression } & \multicolumn{3}{c}{ Quantile Regression } \\
\cline { 2 - 5 } & Pooled & Fixed Effects & $\mathbf{2 5}^{\text {th }}$ & $\mathbf{5 0}^{\text {th }}$ & $\mathbf{7 5}^{\text {th }}$ \\
\hline \multirow{2}{*}{ Constant } & $1.11^{* * *}$ & $1.08^{* * *}$ & $0.01^{*}$ & $0.09^{* * *}$ & $0.37^{* * *}$ \\
& $(0.00)$ & $(0.00)$ & $(0.06)$ & $(0.00)$ & $(0.00)$ \\
COVID & $1.43^{* * *}$ & $1.55^{* * *}$ & $0.15^{* *}$ & $0.55^{* * *}$ & $1.52^{* * *}$ \\
& $(0.00)$ & $(0.00)$ & $(0.01)$ & $(0.00)$ & $(0.00)$ \\
Oil & 39.71 & 26.39 & $12.95^{*}$ & $82.03^{*}$ & $337.37^{*}$ \\
& $(0.42)$ & $(0.58)$ & $(0.07)$ & $(0.06)$ & $(0.09)$ \\
\hline
\end{tabular}

Note: (.) denotes the probability value.

Also, ${ }^{*}{ }^{* *},{ }^{* * *}$ represents level of significance at $10 \%, 5 \%$, and $1 \%$.

On the contrary, the panel quantile regression model highlights that coronavirus outbreak has a positive and statistically significant impact on stock market volatility. 
Our findings align with Zhang et al. (2020) study, which notes the market risk impact of coronavirus outbreaks in developed stock markets. However, we find heterogeneous results across the distribution. At the 25 th quantile, a $0.15 \%$ rise in volatility is fostered by a $1 \%$ increase in deaths from coronavirus. Further, at the 50 th quantile, a $1 \%$ surge in deaths from coronavirus is responsible for a $0.55 \%$ increase in volatility in developed stock markets.

Moreover, at 75th quantile, volatility in developed stock markets escalates by $1.52 \%$ due to a $1 \%$ increase in deaths from coronavirus. Table 4 shows that the coefficient of COVID is increasing with the increase in quantile. The findings from the panel quantile regression model reveal that the coronavirus outbreak generates less volatility in developed stock markets at 25 th quantile and high volatility in markets at 75 th quantile. These results are somehow backed by Baek et al. (2020), who argued that the COVID-19 outbreak surges the stock market volatility. Moreover, Papadamou et al. (2020) note that Google search related to the COVID-19 pandemic positively impacts stock market volatility. Similarly, Uddin et al. (2021) described that the COVID-19 outbreak increases the volatility of 34 developed and emerging stock markets.

Our findings propose that investors should not invest in bearish stock markets during the pandemic as bearish markets are vulnerable to the COVID-19 outbreak. Therefore, the government should initiate measures to stabilize the economy that will eventually keep the stock market safe from the detrimental impacts of the COVID-19 pandemic. Next, bullish stock returns are immune to COVID-19; therefore, investors may invest in these markets in times of outbreaks. It is worth reporting that investors ought to inject their investment in the bullish stock market whenever the wave of the COVID-19 outbreak occurs in order to get capital gains. Moreover, markets with high uncertainty are relatively more vulnerable to COVID-19 outbreaks. Thus, risk-averse investors should not invest in these markets mentioned above during outbreaks. Hence, during the pandemic, it is better to invest in a stock market with meager volatility. Next, COVID-19 harms stock markets; therefore, policymakers should introduce measures to offset the adverse effects of the COVID-19 outbreak. For instance, the US announce quantitative easing to escalate investment. Economies should take these kinds of measures to facilitate investors.

On the contrary, Policymakers from emerging countries have to keep an eye on the policies of developed markets as they have spillover effects on emerging markets. For instance, Syed et al. (2019) conclude that US quantitative easing has a spillover effect on emerging economies' stock markets. Thus, emerging economies should propose policies that could keep the financial markets safe from COVID-19 outbreak and spillover effects from developed economies' quantitative easing.

\section{Conclusion}

This study aims to probe the impact of coronavirus outbreaks on stock market returns and volatility in developed markets. We employ a panel quantile regression model to examine the non-linear effects of coronavirus outbreaks. The findings conclude that 
coronavirus harms stock market returns at the 25th quantile. Moreover, there is an insignificant impact of coronavirus on the stock market at 75 th quantile. Next, there is a positive impact of coronavirus outbreak on stock market volatility. At the 25th quantile, there is a meager impact of coronavirus on stock market volatility. However, at 75 th quantile, there is a profound impact of coronavirus outbreak on stock market volatility.

\section{References}

Abuzayed, B., Bouri, E., Al-Fayoumi, N., \& Jalkh, N. (2021). Systemic Risk Spillover Across Global and Country Stock Markets During the COVID-19 Pandemic. Economic Analysis and Policy, 71, 180-197. https://doi.org/10.1016/j.eap.2021.04.010.

Al-Awadhi, A. M., Al-Saifi, K., Al-Awadhi, A., \& Alhamadi, S. (2020). Death and Contagious Infectious Diseases: Impact of the COVID-19 Virus on Stock Market Returns. Journal of Behavioral and Experimental Finance, 100326. https://doi. org/10.1016/j.jbef.2020.100326.

Alsaifi, K., Elnahass, M., \& Salama, A. (2020). Market Responses to Firms' Voluntary Carbon Disclosure: Empirical Evidence from the United Kingdom. Journal of Cleaner Production, 262, 121377. https://doi.org/10.1016/j.clepro.2020.121377.

Anh, D. L. T., \& Gan, C. (2020). The Impact of The COVID-19 Lockdown on Stock Market Performance: Evidence from Vietnam. Journal of Economic Studies, 48(4), 836-851. https://doi.org/10.1108/JES-06-2020-0312.

Apergis, N., \& Apergis, E. (2020). The Role of Covid-19 for Chinese Stock Returns: Evidence from a GARCHX Model. Asia-Pacific Journal of Accounting \& Economics, 1-9. https://doi.org/10.1080/16081625.2020.1816185.

Ashraf, B. N. (2020). Stock Markets' Reaction to COVID-19: Cases or Fatalities?. Research in International Business and Finance, 54, 101249. https://doi.org/10.1016/j. ribaf.2020.101249.

Baker, S. R., Bloom, N., Davis, S. J., Kost, K. J., Sammon, M. C., \& Viratyosin, T. (2020). The Unprecedented Stock Market Impact of COVID-19. National Bureau of Economic Research Working Paper 26945. https://doi.org/10.3386/w26945.

Baker, S. R., Bloom, N., Davis, S. J., \& Terry, S. J. (2020). Covid-Induced Economic Uncertainty. National Bureau of Economic Research (NBER) Working Paper 26983. https://doi.org/10.3386/w26983.

Baker, S. R., Farrokhnia, R. A., Meyer, S., Pagel, M., \& Yannelis, C. (2020). How Does Household Spending Respond to an Epidemic? Consumption During the 2020 COVID-19 Pandemic. National Bureau of Economic Research Working Paper 24949. https://doi.org/10.3386/w26949.

Baltagi, B.H. (2008). Econometric Analysis of Panel Data. John Wiley and Sons, West Sussex.

Bash, A., \& Alsaifi, K. (2019). Fear from Uncertainty: An Event Study of Khashoggi and Stock Market Returns. Journal of Behavioral and Experimental Finance, 23, 5458. https://doi.org/10.1016/j.jbef.2019.05.004. 
Bhowmik, R., Debnath, G.C., Zafar, R. F., Iormon, B. L. (2021). Creative Industry in Terms of COVID-19 Pandemic: European Countries Responsive Measures. Pressburg Economic Review, 1(1), 9-18.

Binder, M., \& Coad, A. (2011). From Average Joe's Happiness to Miserable Jane and Cheerful John: Using Quantile Regressions to Analyze The Full Subjective WellBeing Distribution. Journal of Economic Behavior \& Organization, 79(3), 275-290. https://doi.org/10.1016/j.jebo.2011.02.005.

Bouri, E. (2015). Return and Volatility Linkages Between Oil Prices and The Lebanese Stock Market in Crisis Periods. Energy, 89, 365-371. https://doi.org/10.1016/j. energy.2015.05.121.

Bouri, E., Cepni, O., Gabauer, D., \& Gupta, R. (2021). Return Connectedness Across Asset Classes Around the COVID-19 Outbreak. International Review of Financial Analysis, 73, 101646. https://doi.org/10.1016/j.irfa.2020.101646.

Bouri, E., Jain, A., Biswal, P. C., \& Roubaud, D. (2017). Cointegration and Nonlinear Causality Amongst Gold, Oil, and The Indian Stock Market: Evidence from Implied Volatility Indices. Resources Policy, 52, 201-206. https://doi.org/10.1016/j.resourpol. 2017.03.003.

Bouri, E., Naeem, M. A., Nor, S. M., Mbarki, I., \& Saeed, T. (2021). Government Responses to COVID-19 and Industry Stock Returns. Economic Research-Ekonomska Istraživanja, 1-24. https://doi.org/10.1080/1331677X.2021.1929374.

Buhagiar, R., Cortis, D., \& Newall, P. W. (2018). Why Do Some Soccer Bettors Lose More Money Than Others?. Journal of Behavioral and Experimental Finance, 18, 85-93. https://doi.org/10.1016/j.jbef.2018.01.010.

Cepoi, C. O. (2020). Asymmetric Dependence Between Stock Market Returns and News During COVID-19 Financial Turmoil. Finance Research Letters, 36, 101658. https:// doi.org/10.1016/j.frl.2020.101658.

Chen, C. D., Chen, C. C., Tang, W. W., Huang, B. Y. (2009). The Positive and Negative Impacts of The SARS Outbreak: A Case of The Taiwan Industries. Journal of Developing Areas, 43(1), 281-293.

Chen, M. H., Jang, S. S., Kim, W. G. (2007). The Impact of The SARS Outbreak on Taiwanese Hotel Stock Performance: An Event-study Approach. International Journal Hospitality Management. 26(1), 200-212.

Činčalová, S., Kiner, A., Chaudhary, V., Syed, Q.R., 2021. Doing Business in Central Europe: The Slovak Republic and The Czech Republic Comparison. Pressburg Economic Review, 1(1), 1-8.

Conlon, T., \& McGee, R. (2020). Safe Haven or Risky Hazard? Bitcoin During The COVID-19 Bear Market. Finance Research Letters, 35, 101607. https://doi. org/10.1016/j.frl.2020.101607.

Delisle, J. (2003). SARS, Greater China, and the Pathologies of Globalization and Transition. Orbis, 47(4), 587-604. http://doi.org/10.1016/S0030-4387(03)00076-0. 
Del Giudice, A., \& Paltrinieri, A. (2017). The Impact of The Arab Spring and The Ebola Outbreak on African Equity Mutual Fund Investor Decisions. Research In Interntional Business and Finance, 41, 600-612. https://doi.org/10.1016/j.ribaf.2017.05.004.

Donthu, N., \& Gustafsson, A. (2020). Effects of COVID-19 on Business and Research. Journal of Business Research, 117, 284-289. https://doi.org/10.1016/j.jbusres.2020.06. 008.

Gao, X., Ren, Y., \& Umar, M. (2021). To What Extent Does COVID-19 Drive Stock Market Volatility? A Comparison Between The US and China. Economic ResearchEkonomska Istraživanja, 1-21. https://doi.org/10.1080/1331677X.2021.1906730.

Goodell, J. W. (2020). COVID-19 and Finance: Agendas for Future Research. Finance Research Letters, 35, 101512. https://doi.org/10.1016/j.frl.2020.101512.

Goodell, J. W., \& Goutte, S. (2020). Co-movement of COVID-19 and Bitcoin: Evidence From Wavelet Coherence Analysis. Finance Research Letters, 38, 101625. https:// doi.org/10.1016/j.frl.2020.101625.

Guo, M., Kuai, Y., \& Liu, X. (2020). Stock Market Response to Environmental Policies: Evidence from Heavily Polluting Firms in China. Economic Modelling, 86, 306-316. https://doi.org/10.1016/j.econmod.2019.09.028.

Hashmi, S. M., Chang, B. H., \& Rong, L. (2021). Asymmetric Effect of COVID-19 Pandemic on E7 Stock Indices: Evidence from Quantile-on-Quantile Regression Approach. Research in International Business and Finance, 58, 101485. https://doi. org/10.1016/j.ribaf.2021.101485.

He, Q., Liu, J., Wang, S., \& Yu, J. (2020). The Impact of COVID-19 on Stock Markets. Economic and Political Studies, 8(3), 275-288. https://doi.org/10.1080/ 20954816.2020.175570.

Hoang, T. H., \& Syed, Q. R. (2021). Investor Sentiment and Volatility Prediction of Currencies and Commodities During The COVID-19 Pandemic. Asian Economics Letters, 1(4), 18642. https://doi.org/10.46557/001x.18642.

Ichev, R., \& Marinč, M. (2018). Stock Prices and Geographic Proximity of Information: Evidence from The Ebola Outbreak. International Review of Financial Analysis. 56, 153-166. https://doi.org/10.1016/j.irfa.2017.12.004.

Kang, W., Ratti, R. A., \& Yoon, K. H. (2015). The Impact of Oil Price Shocks on The Stock Market Return and Volatility Relationship. Journal of International Financial Markets, Institutions and Money, 34, 41-54. https://doi.org/10.1016/j.intfin.2014. 11.002.

Kato, K., \& Galvao, A. F. (2010). Smoothed Quantile Regression for Panel Data. Universitas Narotama-ebooks.

Kilian, L., \& Park, C. (2009). The Impact of Oil Price Shocks on The US Stock Market. International Economic Review, 50(4), 1267-1287. https://doi.org/10.1111/ j.1468-2354.2009.00568.x.

Koenker, R. (2004). Quantile Regression for Longitudinal Data. Journal of Multivariate Analysis, 91(1), 74-89. https://doi.org/10.1016/j.jmva.2004.05.006. 
Kowalewski, O., \& Śpiewanowski, P. (2020). Stock Market Response to Potash Mine Disasters. Journal of Commodity Markets, 20, 100124. https://doi.org/10.1016/j. jcomm. 2020.100124.

Lamarche, C. (2011). Measuring The Incentives to Learn in Colombia Using New Quantile Regression Approaches. Journal of Development Economics, 96(2), 278-288. https://doi.org/10.1016/j.jdeveco.2010.10.003.

Lancaster, T. (2000). The Incidental Parameter Problem Since 1948. Journal of Econometrics, 95(2), 391-413. https://doi.org/10.1016/S0304-4076(99)00044-5.

Lee, C. C., \& Zeng, J. H. (2011). The Impact of Oil Price Shocks on Stock Market Activities: Asymmetric Effect with Quantile Regression. Mathematics and Computers in Simulation, 81(9), 1910-1920.

Li, K. (2018). Reaction to News in The Chinese Stock Market: A Study on Xiong'an New Area Strategy. Journal of Behavioral and Experimental Finance, 19, 36-38. https:// doi.org/10.1016/j.jbef.2018.03.004.

Liu, H., Manzoor, A., Wang, C., Zhang, L., \& Manzoor, Z. (2020). The COVID-19 Outbreak and Affected Countries Stock Markets Response. International Journal of Environmental Research and Public Health, 17(8), 2800.

Liu, L., Wang, E. Z., \& Lee, C. C. (2020). Impact of The COVID-19 Pandemic on The Crude Oil and Stock Markets in The US: A Time-Varying analysis. Energy Research Letters, 1(1), 13154.

Macciocchi, D., Lanini, S., Vairo, F., Zumla, A., Figueiredo, L. T. M., Lauria, F. N., Strada, G., Brouqui, P., Puro, V., Krishna, S., Kremsner, P., Scognamiglio, P., Köhler, C., Nicastri, E., Di Caro, A., Cieri, R. M., Ioannidis, J. P. A., Kobinger, G., Burattini, N, M., Ippolito, G. (2016). Short-term Economic Impact of the Zika virus outbreak. NewMicrobiology, 39(4), 287-289.

Papadamou, S., Fassas, A., Kenourgios, D., \& Dimitriou, D. (2020). Direct and Indirect Effects of COVID-19 Pandemic on Implied Stock Market Volatility: Evidence from Panel Data Analysis. MPRA Paper No. 100020.

Rahman, M. L., Amin, A., \& Al Mamun, M. A. (2021). The COVID-19 Outbreak and Stock Market Reactions: Evidence from Australia. Finance Research Letters, 38, 101832. https://doi.org/10.1016/j.frl.2020.101832.

Shahzad, S. J. H., Naeem, M. A., Peng, Z., \& Bouri, E. (2021). Asymmetric Volatility Spillover Among Chinese Sectors During COVID-19. International Review of Financial Analysis, 75, 101754. https://doi.org/10.1016/j.irfa.2021.101754.

Shanaev, S., \& Ghimire, B. (2019). Is All Politics Local? Regional Political Risk in Russia and The Panel of Stock Returns. Journal of Behavioral and Experimental Finance, 21, 70-82. https://doi.org/10.1016/j.jbef.2018.11.002.

Sharif, A., Aloui, C., \& Yarovaya, L. (2020). COVID-19 Pandemic, Oil Prices, Stock Market, Geopolitical Risk and Policy Uncertainty Nexus in The US Economy: Fresh Evidence From The Wavelet-Based Approach. International Review of Financial Analysis, 70, 101496. https://doi.org/10.1016/j.irfa.2020.101496. 
Smith, R. D. (2006). Responding to Global Infectious Disease Outbreaks: Lessons from SARS on The Role of Risk Perception, Communication and Management. Social Science \& Medicine, 63(12), 3113-3123. https://doi.org/10.1016/j.socscimed.2006. 08.004 .

Sun, Y., Wu, M., Zeng, X., \& Peng, Z. (2021). The Impact of COVID-19 on The Chinese Stock Market: Sentimental or Substantial?. Finance Research Letters, 38, 101838. https://doi.org/10.1016/j.frl.2020.101838.

Syed, Q. R., Malik, W. S., \& Chang, B. H. (2019). Volatility Spillover Effect Of Federal Reserve'S Balance Sheet On The Financial And Goods Markets Of IndoPak Region. Annals of Financial Economics, 14(3), 1950015.

Nippani, S., \& Washer, K.M. (2004). SARS: A Non-Event for A $\mathrm{ff}_{\text {ected Countries' Stock }}$ Markets? Applied Financial Economics, 14(15), 1105-1110. https://doi.org/10.1080/ 0960310042000310579.

Uddin, M., Chowdhury, A., Anderson, K., \& Chaudhuri, K. (2021). The Effect of COVID-19 Pandemic on Global Stock Market Volatility: Can Economic Strength Help to Manage The Uncertainty?. Journal of Business Research, 128, 31-44. https:// doi.org/10.1016/j.jbusres.2021.01.061.

Wang, Y.-H., Yang, F.-J., \& Chen, L.-J. (2013). An Investor's Perspective on Infectious Diseases and Their Influence on Market Behavior. Journal of Business Economics and Management, 14(S1), 112-127. https://doi.org/10.3846/16111699.2012.711360.

Woolridge, J. M. (2010). Econometric Analysis of Cross Section and Panel Data. The MIT Press, Cambridge, MA

Yarovaya, L., Brzeszczynski, J., Goodell, J. W., Lucey, B. M., \& Lau, C. K. (2020). Rethinking Financial Contagion: Information Transmission Mechanism During the COVID-19 Pandemic. SSRN 3602973. https://doi.org/10.2139/ssrn.3602973.

Yousaf, I., Bouri, E., Ali, S., \& Azoury, N. (2021). Gold Against Asian Stock Markets During the COVID-19 Outbreak. Journal of Risk and Financial Management, 14(4), 186-190. https://doi.org/10.3390/jrfm14040186.

Yousfi, M., Zaied, Y. B., Cheikh, N. B., Lahouel, B. B., \& Bouzgarrou, H. (2021). Effects of The COVID-19 Pandemic on The US Stock Market and Uncertainty: A Comparative Assessment Between The First and Second Waves. Technological Forecasting and Social Change, 167, 120710. https://doi.org/10.1016/j.techfore.2021. 120710.

Zhang, D., Hu, M., \& Ji, Q. (2020). Financial Markets Under The Global Pandemic of COVID-19. Finance Research Letters, 36, 101528. https://doi.org/10.1016/j.frl.2020. 101528 .

Zhu, H., Xia, H., Guo, Y., \& Peng, C. (2018). The Heterogeneous Effects of Urbanization and Income Inequality on $\mathrm{CO}_{2}$ Emissions in BRICS Economies: Evidence from Panel Quantile Regression. Environmental Science and Pollution Research, 25(17), 17176-17193. https://doi.org/10.1007/s11356-018-1900-y. 